\section{Synthesis of Tetrahydropyrans through Formal [4+2] Cycloaddition}

Metal-Catalyzed Asymmetric Synthesis and Stereoselective

Reactions

\section{Key words}

Lewis acid catalysis cyclobutanes

tetrahydropyrans

Aromatic aldehydes:<smiles>COC(=O)[C@]1(C(C)=O)CCC1[Tl]</smiles><smiles>O=CO[Na]</smiles>

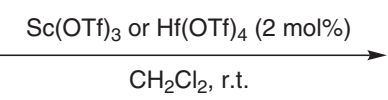

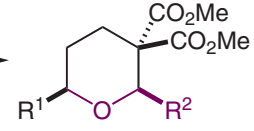

3

$\mathrm{R}^{1}=\mathrm{Ph}, 4-\mathrm{MeOC}_{6} \mathrm{H}_{4}, 4-\mathrm{BrC}_{6} \mathrm{H}_{4},(E)-\mathrm{CH}=\mathrm{CHMe}$

$\mathrm{R}^{2}=\mathrm{Ph}, 4-\mathrm{MeC}_{6} \mathrm{H}_{4}, 3-\mathrm{BrC}_{6} \mathrm{H}_{4}, 4-\mathrm{FC}_{6} \mathrm{H}_{4}, 2-\mathrm{FC}_{6} \mathrm{H}_{4}, 4-\mathrm{F}_{3} \mathrm{CC}_{6} \mathrm{H}_{4}$, 4- $\mathrm{MeOC}_{6} \mathrm{H}_{4}, 3-\mathrm{O}_{2} \mathrm{NC}_{6} \mathrm{H}_{4}, 2-\mathrm{ClC}_{6} \mathrm{H}_{4}, 4-\mathrm{ClC}_{6} \mathrm{H}_{4},(E)-\mathrm{CH}=\mathrm{CHPh}$
11 examples

$\%$ yield

Aliphatic aldehydes:<smiles>COC(=O)[C@]1(C(C)=O)CCC1[Tl]</smiles>

$1=\mathrm{Ph}, 4-\mathrm{MeOC}_{6} \mathrm{H}_{4}, 4-\mathrm{BrC}^{-}$ $\mathrm{R}^{2}=n-\operatorname{Pent}, i-\mathrm{Pr}, \mathrm{Cy}$

$$
{ }_{\text {(3 equiv) }}^{\mathrm{R}_{2}^{2}}
$$

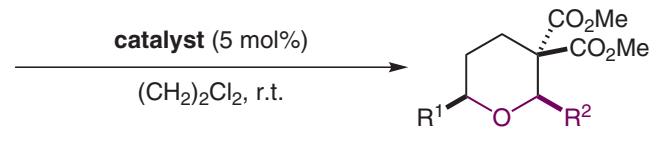

3

6 examples

$68-94 \%$ yield dr from $77: 23$ to $96: 4$

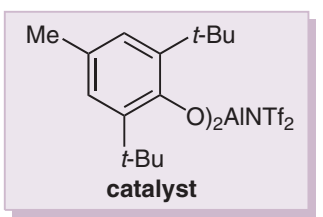

One-pot procedure:

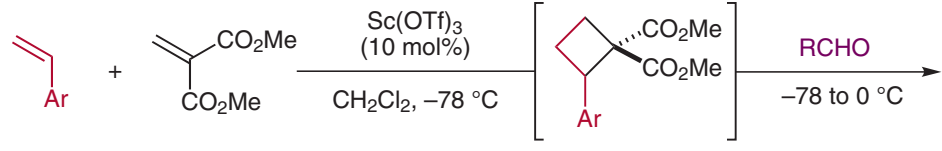

$\mathrm{Ar}=4-\mathrm{MeOC}_{6} \mathrm{H}_{4}$

$\mathrm{R}=\mathrm{Ph}, 3-\mathrm{BrC}_{6} \mathrm{H}_{4}, 4-\mathrm{MeC}_{6} \mathrm{H}_{4}$

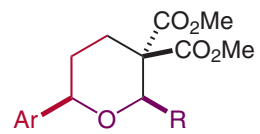

3 examples

$48-63 \%$ yield

dr from $97: 3$ to $98: 2$
Significance: Although insertion reactions with cyclopropanes are well known in organic chemistry, analogous reactivity with cyclobutanes has remained largely overlooked. The authors describe a Lewis acid catalyzed reaction between cyclobutanes and aldehydes to yield substituted tetrahydropyrans in high diastereomeric purity. The reaction is further modified into a formally $\{[2+2]+2\}$ one-pot process, which gives the products in a higher overall yield. In the future of this chemistry, chiral ligands can potentially be applied to yield enantiopure products.
Comment: Both aliphatic and aromatic aldehydes were successfully applied in the transformation, provided that the correct catalyst was used. The mechanism of the reaction is not well understood. In competition experiments products with more electron-rich aldehydes are favored, yet electronpoor aldehydes react more rapidly. The later observation is proposed to result from catalyst poisoning and not from enhanced reactivity. Interestingly, enantiopure starting materials give rise to nearly racemic products, suggesting that racemization of the cyclobutane stereocenter occurs during the reaction. Notably, only cyclobutanes bearing aromatic substituents were utilized $\left(R^{1}=\right.$ $\mathrm{Ar}$ ), which may be a requirement for facile $\mathrm{C}-\mathrm{C}$ bond cleavage.

SYNFACTS Contributors: Mark Lautens, Jane Panteleev DoI: 10.1055/s-0029-1218254; Reg-No.: L14709SF 